\title{
Kreftrisiko etter fertilitetsbehandling i Norge
}

Det er trygt å få behandling med assistert befruktning i Norge, selv om risikoen for enkelte kreftformer øker hos både kvinner og barn.

I 1978 ble verdens første prøverørsbarn født, og det antas at $10 \%$ av alle par nå får behandling for infertilitet. På grunn av økende bruk av infertilitetsbehandling, og at hormoner påvirker utviklingen av enkelte kreftformer, er kreftrisiko i forbindelse med assistert befruktning viktig å undersøke. Kreftrisiko blant norske kvinner behandlet med og barn unnfanget etter infertilitetsbehandling har ikke tidligere vært studert.

Data fra tre norske populasjonsbaserte registre ble brukt: Medisinsk fødselsregister, Kreftregisteret og Reseptregisteret. Totalt sett var ikke kreftrisikoen høyere hos kvinner behandlet med assistert befruktning enn blant ubehandlede kvinner. Enkelte kreftformer viste seg imidlertid å forekomme hyppigere blant behandlede kvinner. Brystkreftrisikoen økte med $20 \%$, spesielt blant kvinner som fikk barn etter prøverørsbehandling. Kvinner som forble barnløse etter assistert befruktning, hadde høyere risiko for eggstokkreft og livmorkreft. Prøverørsbarn var noe mer utsatt for å få leukemi enn sine jevngamle, men totalt sett hadde de ikke høyere risiko for kreft. Studien avdekker ikke om det er behandlingen eller det å være infertil som gir økt risiko.

Studien viser at det er trygt å få behandling med assistert befruktning i Norge. Der man påviste risikoøkning, er det snakk om få krefttilfeller i utgangspunktet, og en risikoøkning vil svare til få tilfeller per år. Likevel er det viktig at disse kvinnene og deres barn følges videre, også $i$ årene som kommer.

Marte Myhre Reigstad martereigstad@gmail.com

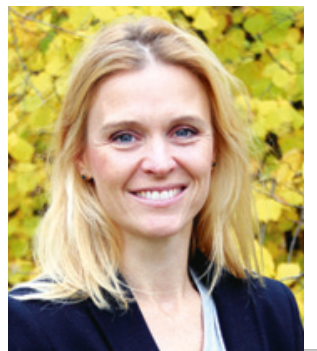

Marte Myhre Reigstad. Foto: Elisabeth Jakobsen

\section{Disputas}

Marte Myhre Reigstad disputerte for ph.d.graden ved Universitetet i Oslo 18. november 2016. Tittelen på avhandlingen er Risk of cancer after fertility treatment in Norway. Populationbased studies on women treated with and children conceived by assisted reproduction.

\section{Sjukefråvær og rehabilitering etter traumatisk hjerneskade}

Tverrfagleg poliklinisk behandling gav færre plager etter hjerneskade og mindre bruk av andre helsetenester, men påverka ikkje sjukefråværet.

Om lag 9000 personar vert årleg innlagt i sjukehus i Norge med ein lett traumatisk hjerneskade. Ei mindre gruppe utviklar langvarige kognitive, emosjonelle og fysiske vanskar som reduserer arbeidsevna og kan føre til varig arbeidsuførleik.

I mitt doktorgradsarbeid har eg systematisk kalla inn alle som har vore innlagt ved Haukeland universitetssjukehus og Oslo universitetssjukehus, Ullevål, til oppfølging to månader etter lett traumatisk hjerneskade i ein treårs periode. Av 866 pasientar som var innlagt i aldersgruppa 16-55 år, vart 151 pasientar vurdert til å trenge vidare oppfølging. Desse vart inkludert i ein randomisert kontrollstudie der tverrfagleg poliklinisk behandling vart samanlikna med vidare oppfølging hjå fastlege etter tverrfagleg undersøking. Det var ikkje forskjell i sjukefråvær mellom gruppene, men dei som fekk tverrfagleg poliklinisk behandling, hadde signifikant færre plager etter hjerneskaden og tendens til mindre bruk av andre helsetenester.

Studien kan tyde på at også arbeidsgjevar må involverast tidleg for å få fleire tilbake $i$ arbeid. Studien, kor ein nytta trygdedata, tyder på at det berre er eit mindretal av pasientane som treng oppfølging etter ein lett traumatisk hjerneskade. Pasientar som har hatt episodar med sjukmelding før skaden, dårleg funksjonsnivå og psykisk reaksjon etter skaden, står i fare for langvarig sjukmelding med behov for vidare oppfølging. Det var ingen sikker samanheng mellom funn på CT-bilete og utfallet.

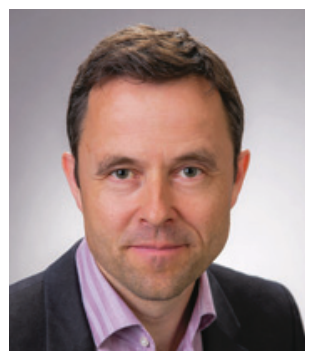

Eirik Vikane. Foto: Anne Sidsel Herdlevær

Disputas

Eirik Vikane disputerte for ph.d.-graden ved Universitet i Bergen 10. juni 2016. Tittelen på avhandlinga er Effect of multidisciplinary outpatient treatment after mild traumatic brain injury - A randomised controlled trial and prognostic factors. 